\title{
Oligometastasis and oligo-recurrence: more than a mirage
}

\author{
Fang Huang, Gang Wu ${ }^{*}$ and Kunyu Yang ${ }^{*}$
}

\begin{abstract}
The standard treatment choice for cancer metastasis has been systemic management, including cytotoxic chemotherapy, hormonal manipulation, and targeted therapy. Emerging evidence has shown an oligometastatic state, an intermediate state between limited primary cancer and polymetastatic cancer, in which local therapy for metastatic lesions results in satisfactory survival comparable to non-metastatic disease. We provide a comprehensive introduction of evidence from experimental and clinical studies in favor of the oligometastatic phenotype, we review the efficacy and safety of surgery and stereotactic body radiotherapy in the treatment of oligometastases, and finally, we discuss the way to differentiate the oligometastatic state from polymetastasis.
\end{abstract}

Keywords: Oligometastasis, Oligo-recurrence, Surgery, SBRT, Survival

\section{Introduction}

Cancer is widely regarded as a systemic disease. Previously, cancer with metastasis has been considered stage $\mathrm{IV}$, an end-stage disease, with the goal of palliative management. The standard treatment choice for metastatic cancer has been systemic management, including cytotoxic chemotherapy, hormonal manipulation, and targeted therapy. Despite recent advances in systemic therapy, prognosis remains poor. Within the population of cancer metastasis, emerging evidence has shown that a fraction of patients have an oligometastatic state, in which local therapy for metastatic lesions results in satisfactory survival comparable to non-metastatic disease. The concept of an oligometastatic state was first proposed by Hellman et al. as an intermediate state ( $\leq 5$ metastases) between limited primary and polymetastatic cancers in which local therapy could achieve long-term survival or cure, with no restrictions on primary lesions [1,2]. In 2006, the concept of oligo-recurrence was defined by Niibe $e t a l$. as the state that cancer patients have $\leq 5$ metastatic or recurrent lesions with controlled primary lesions [3]. Recently, the concept of sync-oligometastasis was proposed as the state that cancer patients have $\leq 5$ metastatic or recurrent lesions with active primary lesions [4]. The major difference among oligometastasis, oligo-recurrence and

\footnotetext{
*Correspondence: xhzlwg@163.com; yangky71@aliyun.com

Wuhan Union Hospital, Tongji Medical College, Huazhong University of Science and Technology, Wuhan 430022, Hubei, China
}

sync-oligometastasis was the status of the primary lesion, which is the most important prognostic factor of oligometastasis, and oligo-recurrence showed better prognosis compared with sync-oligometastasis.

Despite the accumulating knowledge on this state, the existence of oligometastasis remains debatable. Although oligometastatic clones are not identified directly, some clonal areas with modest metastatic capacities might lead to oligometastasis, at least in a fraction of all metastatic cases. During the past decades, a large amount of data has shown excellent 5-year survival rates after aggressive local treatment of metastatic disease for many patients, including those with a limited number of metastases, certain primary tumor types, and early $\mathrm{T}$ - and $\mathrm{N}$-stage primary tumors. However, many oncologists believe oligometastasis is more like a mirage than a reality. In this review, we provide a comprehensive introduction of evidence favoring the oligometastatic phenotype, we review the efficacy and safety of two methods to treat metastatic lesions [surgery and stereotactic body radiotherapy (SBRT)], and finally, we discuss the manner in which oligometastasis can be differentiated from polymetastasis.

\section{Review}

Biological basis of the oligometastatic phenotype

Metastasis occurs when genetically unstable cancer cells colonize a tissue microenvironment distant from the primary tumor. With advances in genomic research 
techniques, including next-generation sequencing and high-resolution genome-wide SNP and copy number analyses, emerging evidence indicates that clones with selective advantages within the primary tumor give rise to distant metastasis. Navin et al. applied single-nucleus sequencing to investigate the genetic relationship between a primary breast cancer tumor and its liver metastasis [5], they found that copy number profiles from the primary tumor were highly similar to those from the metastases, indicating that metastatic cells emerge from a main advanced expansion rather than from an earlier intermediate or a completely different subpopulation.

Primary tumors are composed of heterogeneous cell populations, and evidence over the years has shown that tumor clones are not equally able to metastasize. Fidler et al. identified a wide range of metastatic ability of B16F1 melanoma cells to colonize the lung [6], supporting the notion of clonal heterogeneity within the primary tumor. Various cell lines with high and low metastatic potential have also been reported in $\mathrm{PC}-14$ human lung adenocarcinoma cells [7] and MHCC97 hepatocellular carcinoma cells [8], and these results have been expanded upon by investigators using KHT sarcoma cells [9].

Further important evidence implying the existence of oligometastasis was proposed by Yachida et al. who used next-generation sequencing techniques to analyze the genomes of seven patients with pancreatic cancer metastases in order to evaluate the clonal relationships between the primary and metastatic cancers [10]. Quantitative analysis of the genetic evolution of pancreatic cancer indicated at least a decade between the initiating mutation and the birth of the cancer cell, another five years were required for acquisition of metastatic ability. This temporal nature emphasizes that oligometastastic clones might develop before polymetastatic clones during tumorigenesis.

During this time, intensive research on metastasisregulating genes has also advanced. Although the genes responsible for the oligometastastic phenotype remain elusive, DNA array analysis has provided important information to distinguish oligometastasis from polymetastasis. Wuttig et al. used samples from patients with renal cell carcinoma to identify genes that characterized 'few' $(<8)$ or 'many' $(>16)$ pulmonary metastases [11]. Analysis of fresh samples from resection of pulmonary metastases revealed 135 genes that were differentially expressed between the 'few' and 'many' metastasis groups. Furthermore, polymetastatic tumors were enriched by genes that regulate the cell cycle. Based on a meta-analysis of these data and previously published data, an 11-gene classifier was established to predict the number of metastases in patients with renal cell carcinoma. These data provide evidence at the molecular level for the existence of an oligometastastic state, but further work is essential to clarify mechanisms that generate the oligometastastic phenotype.

\section{Clinical supporting evidence and treatment options for oligometastases \\ Liver oligometastases}

The liver is frequently involved in cancer metastasis, especially in cancers from the gastrointestinal tract. This susceptibility is attributed to venous drainage of the gastrointestinal tract via the portal vein and to the liverspecific microenvironment suitable for colonization by certain types of tumor. Local therapy, including surgery and SBRT of liver metastatic lesions, has significantly improved survival in these patients. Much evidence exists showing the efficacy of surgical resection of hepatic metastases from colorectal cancer, with 10-year overall survival (OS) rates of $17-28 \%$, which is far better than those of patients treated with systemic therapy [12].

Long-term survival after resection for non-colorectal cancer liver metastases has also been documented. A systematic review of $>1000$ patients with breast cancer and liver metastasis showed 2-, 3- and 5-year survival rates of $58-86 \%, 35-79 \%$ and $21-61 \%$, respectively [13]. Liver metastasectomy of neuroendocrine tumors (NET) has also been shown to benefit most patients (95\%) and prolong survival [14]. A systematic review of NET liver metastasectomy reported median 5- and 10-year OS rates of $70.5 \%$ and $42 \%$, respectively, and median 1-, 3 - and 5-year progression free survival (PFS) rates of $63 \%, 32 \%$ and $29 \%$, respectively, which are much better than those from other tumor origins. Hepatectomy of metastases from melanoma also nearly doubles survival, with a median OS of 14 months after surgery increased to 27 months with R0 resection [15]. Summary of hepatic metastasectomy from selected studies were listed in Table 1.

Table 1 Summary of hepatic metastasectomy from selected studies

\begin{tabular}{llllll}
\hline Primary tumor type & Year & No. patients & 5-year survival (\%) & 10-year survival (\%) & References \\
\hline Noncolorectal & 2005 & 142 & 26 & $/$ & {$[16]$} \\
Noncolorectal Nonendocrine liver metastases & 2006 & 1452 & 36 & 3 & {$[17]$} \\
Noncolorectal nonneuroendocrine liver metastases & 2007 & 360 & 37 & 4 & {$[18]$} \\
Breast cancer & 2010 & 41 & 48 & $/$ & {$[19]$} \\
Soft-tissue sarcoma & 2009 & 45 & 49 & {$[20]$} \\
\hline
\end{tabular}


Although surgical resection is the optimal choice for patients with liver oligometastases, unfortunately, only some patients are eligible for metastasectomy at diagnosis [21]. It is difficult to eradicate gross tumors using conventional radiotherapeutic techniques without accompanied radiation-induced liver disease because of the relative radiosensitivity of the liver [22]. Stereotactic body radiotherapy allows delivery of ablative doses of radiation to metastatic lesions. The efficacy and tolerability of SBRT for liver metastasis has been confirmed by retrospective studies [23-26] showing local control rates around $80 \%$ or higher [27]. At Centre Oscar Lambret, 42 patients with 62 liver metastases were treated with SBRT at 40 Gy in 4 fractions and 45 Gy in 3 fractions. 1- and 2 -year local control rates were $90 \%$ and $86 \%$, respectively, and 1 - and 2 -year OS rates were $94 \%$ and $48 \%$, respectively. In all, $38 \%$ of patients suffered grade 1 or 2 toxicity, and one patient had grade 3 epidermitis. Summary of SBRT for liver metastasis from selected studies were listed in Table 2.

Although many reports on SBRT for liver metastases are retrospective, prospective trials have been initiated as well. In phase I trials, maximum tolerated doses of SBRT were determined using a range of therapeutic doses in various fractions. In all, 60 Gy was well tolerated and safe and was commonly used as the therapeutic dose in phase II clinical trials. 1- and 2-year local control rates in prospective studies ranged $71-95 \%$ and $82-92 \%$, respectively, with no grade 4-5 liver toxicity and few grade 3 toxicities [28-34]. Preliminary reports from a 2013 phase II trial of 61 patients with 3 or more lesions receiving 75 Gy on 3 consecutive days showed a $94 \%$ infield local response rate at 1-year, median OS of 19 months and actuarial survival of $83.5 \%$ at 12 months. Grade 3 late toxicity occurred in one patient, with no grade 3 or higher acute toxicity. SBRT offers an alternative, noninvasive approach for patients with liver metastases. The outcomes of serial studies confirm that it is a promising treatment modality with efficacy and safety, bringing benefit to patients with unresectable lesions.

\section{Lung oligometastases}

Lung metastasis is also a major cause of cancer death, and the lung is the primary venous drainage organ for the entire body except the gastrointestinal tract. The lung is the most extensively studied organ for cancer microenvironment because of its susceptibility to metastasis. Local therapy for patients with lung oligometastases is not new and significantly prolongs survival. Many retrospective surgical studies have shown that patients with limited metastases can have a long-term survival, indicating that limited metastasis may be eliminated in these patients [35-41]. The particular study by Pastorino et al. (1997) is of great importance [35]. They assessed the long-term results of 5206 cases of lung metastases from different origins treated with surgery included in the International Registry of Lung Metastases. The 5-year OS rate of patients with complete metastasectomy was $36 \%$, but it was only $13 \%$ for those with incomplete resection. A prospective study including 1720 patients with pulmonary metastatic melanoma showed that metastasectomy is a strong predictor of survival with the hazard ratio of 0.5 (95\% CI: 0.4-0.6) [40]. Summary of pulmonary metastasectomy from selected studies were listed in Table 3.

SBRT has been shown to prolong OS or even induce a cure in lung oligometastases, which is especially attractive for patients who refuse or are unsuitable for resection. Results of retrospective studies have shown 2-year local control rates ranging $80-90 \%$ and 2-year OS rates ranging 66-84\% [48-52]. These results were repeated in a 2010 systematic review involving 334 patients, in which the 2-year weighted local control rate was $77.9 \%$, and the 2 -year weighted OS rate was $53.7 \%$. Recently, Takahashi et al. conducted a retrospective analysis of 42 patients with lung oligo-recurrence who underwent SBRT, 2-year local control rate and 2-year OS rate were $87 \%$ and $65 \%$

Table 2 Summary of SBRT for liver metastasis from selected studies

\begin{tabular}{|c|c|c|c|c|c|}
\hline Primary tumor type & Year & No. patients & Local control & Toxicity & References \\
\hline $\begin{array}{l}\text { Mixed (Most colorectal } \\
\text { cancer) }\end{array}$ & 2001 & 37 & $81 \%$ at 18 month & not mentioned & {$[28]$} \\
\hline Mixed & 2006 & 36 & $93 \%$ at 18 months & $\begin{array}{l}\text { one case of grade } 3 \text { soft tissue } \\
\text { toxicity }\end{array}$ & [29] \\
\hline $\begin{array}{l}\text { Mixed (Most colorectal } \\
\text { cancer) }\end{array}$ & 2009 & 68 & 1-year local control rate was $71 \%$ & $\begin{array}{l}9 \% \text { acute grade } 3 \text { toxicities and } \\
1 \% \text { grade } 4 \text { toxicity }\end{array}$ & [30] \\
\hline $\begin{array}{l}\text { Mixed (Most colorectal } \\
\text { cancer) }\end{array}$ & 2006 & 25 & $\begin{array}{l}1 \text { - and } 2 \text {-year local control rates were } 94 \% \\
\text { and } 82 \%\end{array}$ & 4 cases of grade $\geq 3$ toxicity & [31] \\
\hline $\begin{array}{l}\text { Mixed (Most colorectal } \\
\text { cancer) }\end{array}$ & 2011 & 27 & $\begin{array}{l}30-, 50-\text {, and } 60-\text { Gy cohorts were } 56 \%, 89 \% \text {, and } \\
100 \% \text { at } 24 \text { months respectively }\end{array}$ & one case of grade 3 toxicity & [32] \\
\hline Mixed & 2009 & 47 & $\begin{array}{l}1 \text { - and 2-year local control rates were } 95 \% \\
\text { and } 92 \%\end{array}$ & $\begin{array}{l}\text { actuarial rate of grade } \geq 3 \text { toxicity } \\
\text { was } 2 \%\end{array}$ & [33] \\
\hline
\end{tabular}


Table 3 Summary of pulmonary metastasectomy from selected studies

\begin{tabular}{|c|c|c|c|c|c|}
\hline Primary tumor type & Year & No. patients & 5-year survival (\%) & 10-year survival (\%) & References \\
\hline Melanoma & 2007 & 1720 & 21 & / & {$[40]$} \\
\hline Many types & 2011 & 575 & 46 & / & [37] \\
\hline Colorectal carcinoma & 2002 & 165 & 39.6 & 37.2 & [41] \\
\hline Colorectal carcinoma & 2007 & 175 & 53.8 & 20.6 & [42] \\
\hline Renal cell carcinoma & 2002 & 191 & 41.5 & / & {$[38]$} \\
\hline Renal cell carcinoma & 2011 & 202 & 39 & / & [43] \\
\hline Testicular germ cell tumors & 1998 & 157 & 68 & / & {$[44]$} \\
\hline Malignant fibrous histiocytoma & 2005 & 103 & 21 & / & [45] \\
\hline Gynecologic cancers & 2006 & 103 & 46.8 & 34.3 & [46] \\
\hline Bone sarcoma & 2010 & 52 & 31 & / & {$[47]$} \\
\hline
\end{tabular}

respectively [53]. Interestingly, the efficacy and feasibility of carbon ion radiotherapy for lung oligo-recurrence were evaluated in a retrospective study, 3-year local control rate was $85.4 \%$ and 3 -year OS rate was $50.1 \%$, without any grade 3-5 toxicity [54]. The safety and efficacy of SBRT for lung oligometastases has been confirmed by prospective phase I and II trials. In one multi-institutional phase I/ II trial, use of SBRT at 48-60 Gy in 3 fractions showed no dose-limiting toxicities. In all, 60 Gy was delivered in phase II, and 1- and 2-year actuarial local control rates were $100 \%$ and $96 \%$, respectively. The median survival was 19 months. Grade 3 toxicity occurred in $8 \%$ of patients with no grade 4 or higher toxicity [55]. Other prospective studies have shown similar results [56,57], which are comparable to survival after surgery. In summary, increasing evidence proves that SBRT is efficacious and well tolerated in patients with lung metastases. Summary of SBRT for lung metastasis from selected studies were listed in Table 4.

\section{Adrenal oligometastases}

Adrenal metastases, mostly lung and renal in origin, are reported to occur in $13-27 \%$ of disseminated malignancies at autopsy [61]. Although debates exist on adrenal metastasectomy, several retrospective studies have shown that both open and laparoscopic adrenalectomy prolongs survival $[62,63]$. In a 2012 retrospective study by Zheng et al., $31 / 47$ patients had adrenal metastasectomy, and survival rates were significantly higher in patients with surgery than in patients without surgery $(34.2 \pm 4.7$ vs. $6.3 \pm$ 2.7 months, respectively). Data on SBRT for treating adrenal metastases is limited. Several studies show that it is an invasive but effective and safe option [64,65]. Casamassima et al. studied 48 patients with adrenal metastases who were treated with SBRT at $36 \mathrm{~Gy} / 3$ fractions. Actuarial 1- and 2-year local control rates were $90 \%$, and actuarial OS rates at 1 and 2 years were $39.7 \%$ and $14.5 \%$, respectively.

\section{Spinal oligometastases}

Bone metastases account for $20 \%$ of patients with metastatic tumors, and the most common site is the axial skeleton. Spinal metastases often cause pain and diminished quality of life. Palliative surgery benefit patients with spinal metastasis by improving quality of life [66,67]. SBRT has emerged as a novel, promising and non-invasive

Table 4 Summary of SBRT for lung metastasis from selected studies

\begin{tabular}{|c|c|c|c|c|c|}
\hline Primary tumor type & Year & $\begin{array}{l}\text { No. } \\
\text { patients }\end{array}$ & Local control & Toxicity & References \\
\hline Mixed & 2006 & 50 & 3-year local control rate $83 \%$ & $\begin{array}{l}35 \% \text { Grade } 1 \text { toxicity, } 6.1 \% \text { grade } 2 \text { toxicity, } \\
2 \% \text { grade } 3 \text { toxicity }\end{array}$ & {$[51]$} \\
\hline Mixed (Most NSCLC) & 2009 & 124 & 3-year local control rate $83 \%$ & $17.8 \%$ Grade 2 toxicity, $1.2 \%$ grade 3 toxicity & {$[48]$} \\
\hline $\begin{array}{l}\text { Mixed (Most colorectal } \\
\text { cancer) }\end{array}$ & 2010 & 10 & $\begin{array}{l}1 \text { - and } 2 \text {-year local control rates } \\
\text { were } 48 \% \text { and } 25 \%\end{array}$ & Not mentioned & {$[58]$} \\
\hline $\begin{array}{l}\text { Mixed (Most colorectal } \\
\text { cancer) }\end{array}$ & 2011 & 44 & $\begin{array}{l}\text { 1- and } 2 \text {-year local control rates in } \\
\text { colorectal cancers were } 80 \% \\
\text { and } 72 \%\end{array}$ & $\begin{array}{l}2 \text { cases of Grade } 2 \text { radiation pneumonitis, } \\
1 \text { case of Grade } 3 \text { pneumonitis, No Grades } \\
4 \text { radiation pneumonitis }\end{array}$ & {$[59]$} \\
\hline Mixed (Most NSCLC) & 2012 & 61 & $\begin{array}{l}\text { 2- and } 3 \text { - year local control rates } \\
\text { were } 89 \% \text { and } 83.5 \%\end{array}$ & one case of grade 3 radiation pneumonitis & {$[52]$} \\
\hline $\begin{array}{l}\text { Mixed (Most colorectal } \\
\text { cancer) }\end{array}$ & 2013 & 32 & $\begin{array}{l}1-, 2 \text { - and } 3-\text { year local control } \\
\text { rates were } 97 \%, 92 \% \text { and } 85 \%\end{array}$ & $\begin{array}{l}\text { no grade } 4 \text { toxicity, } 3 \text { cases of grade } 3 \text { toxicities, } \\
1 \text { case of grade } 2 \text { radiation pneumonitis }\end{array}$ & {$[60]$} \\
\hline
\end{tabular}


treatment modality for isolated spinal metastasis $[68,69]$. In a phase I/II trail, 149 patients with 166 non-cord compressing spinal metastases were treated with 27-30 Gy SBRT, generally in 3 fractions. Actuarial survival rates at 1 and 2 years were $71.9 \%$ and $48.8 \%$, respectively. The actuarial local control rates at 1 and 2 years after SBRT were $80.5 \%$ and $72.4 \%$, respectively. Few grade 3 and no grade 4 or higher toxicities were observed. Compared to surgery, SBRT may better benefit patients with prolong survival, pain relief and safety. However, it should be noted that SBRT is associated with vertebral compression fractures $[70,71]$.

\section{Long-term follow-up data of oligometastases treated by SBRT}

Although there are no prospective randomized studies comparing the long-term survival of SBRT and metastasectomy, the recent prospective study by Widder et al. found that the long-term survival of patients with pulmonary oligometastases treated with SBRT is not inferior to that of metastasectomy. In this study, the 5-year OS rates were $41 \%$ for metastasectomy and $49 \%$ for SBRT ( $\mathrm{p}=0.43)$ [72].

Several studies have shown better prognosis in longterm survivors who had been treated with SBRT. Recently, de Vin et al. retrospectively studied 309 oligometastatic cancer patients treated with SBRT. They showed a 5-year OS rate of $32 \%$, and they identified a subgroup of longterm survivors with a median survival of 40 (24-63) months [73]. Moreover, a prospective study by Milano et al. of 121 patients with oligometastases treated with SBRT showed a 6 -year OS rate of $20 \%$, and they identified selected long-term breast cancer survivors with a 6-year OS rate of $47 \%$ [74]. Clearly, the key issue for prospective randomized trials to verify the promising benefit of SBRT in patients with oligometastases will be how to identify the most suitable population for radical local treatment.

\section{Clinical factors in selecting patients with oligometastases}

The satisfactory outcomes of local therapy for oligometastases strongly suggest the existence of an oligometastatic phenotype, but the frequency of oligometastases in various cancer types is unknown, and there are no standard criteria used to identify these patients. However, several clinical prognostic factors have been identified which strongly suggest the oligometastatic state and aid in selecting patients for aggressive local therapies.

\section{Colorectal cancer}

Liver is the most common site of metastasis from colorectal cancer, and more than half of patients with colorectal cancer will develop liver metastases during the disease course. As early as the 1980 s, a subpopulation of patients with isolated liver metastases and a better prognosis was identified [75], and hepatic resection has become the standard treatment for resectable liver metastases from colorectal cancer. Recent data on the efficacy of this surgical resection has demonstrated a 5-year OS rate of 39-47\% and a 10 -year OS rate of $17-28 \%$, which is far better than for those who received systemic therapy $[76,77]$. These long-term survivors strongly support the biological distinction of oligometastases in colorectal cancer. Simmonds et al. performed a review of 529 independent studies evaluating the benefit of hepatic resection of oligometastases from colorectal cancer and found a majority of retrospective studies and an absence of prospective randomized trials [78], indicating the need for further studies of this population.

Approximately $10-15 \%$ of patients with colorectal cancer will develop lung metastases, and pulmonary metastasectomy is the standard treatment for resectable lesions. Evidence suggests that patients with isolated lung metastases have a better prognosis after resection, with a 5-year OS rate of $40-61 \%[79,80]$. Salah et al. reviewed 8 retrospective studies of pulmonary metastasectomy in 988 colorectal cancer patients, and the 5-year OS rate was 54.3\% following the first lung resection [81]. Moreover, after further stratification into the population into good, intermediate, and high-risk groups according to three independent prognostic factors (CEA, disease free interval and lesion numbers), the 5-year OS were $68.2 \%, 46.4 \%$ and $26.1 \%$, respectively; in this, the good and intermediate groups had OS comparable to patients with stage III colorectal cancer.

Although there is a lack of randomized controlled data on local therapy for metastases from colorectal cancer, the promising long-term survival suggests a potential cure in the oligometastatic population, while this survival is rare in patients with extensive metastases.

\section{Breast cancer}

The survival benefit of pulmonary metastasectomy for patients with breast cancer has been reported in retrospective studies, but until recently, no prospective randomized trials have been available to validate the existence of oligometastases in breast cancer and to explore the impact of local therapy. Recently, Meimarakis et al. studied the role of metastasectomy in breast cancer patients with oligometastases, at least partially [82]. They reported 5- and 10 -year OS rates of $59.6 \%$ and $43.0 \%$, respectively, which were significantly higher than those of patients treated regularly.

Liver metastases of breast cancer are usually part of generalized metastases and indicate a poor prognosis with a median OS of 4-12 months, but selected $(<5 \%)$ patients with isolated liver metastases have shown good long-term survival after metastasectomy of liver lesions. A systematic review by Bergenfeldt et al. analyzed 
patients with breast cancer and liver oligometastases who had undergone metastasectomy and patients who had received local ablation therapy such as SBRT, they showed that surgical resection led to 5-year OS rates of $25-42 \%$, that local ablation therapy had similar survival results, and R0 resection was a strong prognostic factor for survival [13].

\section{Non-small cell lung cancer (NSCLC)}

A systematic review by Ashworth et al. analyzed 49 retrospective studies of 2176 patients with NSCLC treated with metastasectomy and found highly variable survival outcomes, with 5 -year OS rates of $10-80 \%$ and more than half of oligometastatic lesions progressing within 12 months after metastasectomy [83]. Interestingly, two randomized controlled trials, primarily of patients with NSCLC, have provided compelling evidence in support of an oligometastatic state. In 1990, Patchell et al. reported that patients with a single brain metastasis who had undergone metastasectomy plus radiotherapy had longer survival than those who had received radiotherapy alone [84]. In a randomized multi-institutional trial, 333 patients (64\% NSCLC) with brain metastases received whole-brain radiation therapy with or without an SBRT boost; results for patients with a single brain metastases showed that the combination therapy group had a survival advantage compared to the whole-brain radiation group (median OS 6.5 vs 4.9 months, $\mathrm{p}=0.039$ ) [85].

\section{Other tumor origins}

The different histology of tumors greatly influences prognosis, and this fact should be taken into account when determining patient treatment. Studies have shown that tumors from particular origins have a better prognosis after local therapy. Pulmonary metastases from germ cell tumors, hepatic metastases from neuroendocrine tumors (NET), and breast cancer oligometastases all have relatively prolonged survival, while hepatic metastasis from gastric cancer has a worse prognosis. A 2011 retrospective study of 575 patients and 708 lesions by Casiraghi et al. showed that tumor origin predicts prognosis after pulmonary metastasectomy, with 5-year survival rates of $46 \%, 39 \%, 37 \%$ and $90 \%$ for epithelial, sarcoma, melanoma and germ cell cancers, respectively.

\section{Number of metastases in selecting patients with oligometastases}

The number of metastatic lesions is known to influence prognosis, but the concrete number of lesions has not been determined. Several important studies confirmed that 4 metastases is a critical value. A systematic review of 15 studies by Spelt et al. demonstrated that number of metastases was a prognostic factor in all prospective studies and in $8 / 11$ retrospective studies, and that number of metastases correlated best with survival [86].

\section{DFI in selecting patients with oligometastases}

DFI has generally been considered a prognostic factor in lung metastases other than liver metastases. The value of DFI has not been standardized, however, and varies between 12, 23 and 36 months in different studies. Kanzaki et al. studied patients with pulmonary metastasectomy from renal cell carcinoma and demonstrated that a DFI $\geq 2$ years was associated with a 5 -year survival of $58 \%$ but that the survival of patients with DFI $<2$ years decreased to $26 \%$ [87]. DFI has also been found to be a prognostic factor after pulmonary local therapy. Pfannschmidt et al. demonstrated a 5-year survival rate of $24.7 \%$ in patients with DFI $<23$ months compared to $47 \%$ for those with DFI $>23$ months [33].

\section{$N$ stage in selecting patients with oligometastases}

Involvement of lymph nodes, also termed $\mathrm{N}$ staging, is a risk factor in several tumor types, particularly in liver metastases other than pulmonary metastases. Negative lymph node status predicts a better prognosis than positive status after local therapy. In a study of 925 patients by Rees et al. to evaluate factors associated with prognosis after liver metastasectomy for colorectal cancer, primary lymph node status was identified as a prognostic factor, and 5 -year survival was $42.2 \%$ with lymph node-negative status and $31.8 \%$ with lymph-node-positive status [88].

\section{Scoring systems in selecting patients with oligometastases}

Scoring systems, which aim to predict prognosis before local therapy, are useful because individual patients have different prognostic factors. Myrddin et al. performed a prospective study of 929 patients to identify prognostic factors after hepatic resection for metastatic colorectal cancer [88], and the Basingstoke Predictive Index was created based on the following prognostic factors: primary lymph node status, primary tumor differentiation, CEA level at hepatectomy, metastatic number, largest tumor diameter and extrahepatic metastatic disease. Patients were given a total score based on the prognostic factors and were divided into the following groups: 0,5 , $10,15,20,25$, and 30. Five-year survival in patients with the lowest scores was $66 \%$, decreasing to only $2 \%$ in patients with the highest scores. Similar results have been observed in other scoring systems, including Risk score, the Memorial Sloan Kettering Cancer Center clinical risk score and simplified cancer staging systems [89-91].

\section{MiroRNA signature in selecting patients with oligometastases}

MicroRNA is known to regulate proliferation and apoptosis in cancer development, and microRNA expression 
profiles may be better able to classify cancer subtypes than coding gene profiles. Emerging evidence indicates that microRNA profiles could be a useful tool to distinguish oligometastasis from polymetastasis. Recently, Lussier et al. analyzed microRNA expression patterns from lung metastasis samples of patients with 1-5 metastatic tumors resected with curative intent [92] and identified distinct microRNA profiles between patients with the highest and lowest rates of recurrence. Another clinical/ pathologic correlation study indicated that microRNA200c expression was able accurately to characterize patients with clinically limited metastases into two phenotypes-those whose disease progressed to widespread, polymetastatic recurrence and those with clinically limited disease or oligometastatic recurrence [92].

\section{Conclusions}

Given the abundant clinical and biological evidence supporting the oligometastatic state, we infer that oligometastasis is more than a mirage. As understanding of the biology of metastases increases, improved biomarkers to accurately identify patients with oligometastases will be generated, allowing better selection for locally ablative therapies. Furthermore, prospective trials will be needed to clarify the criteria for selecting patients with oligometastases from each specific cancer type, and randomized trials comparing the efficacy and safety of different treatment modalities including SBRT or surgery will also be needed to generate guidelines for the treatment of oligometastasis. With the advance of molecular and clinical medicine, the oligometastasis mirage might be converted to a paradigm of cancer treatment.

\section{Abbreviations \\ SBRT: Stereotactic body radiotherapy; OS: Overall survival; \\ NET: Neuroendocrine tumors; PFS: Progression-free survival; \\ DFI: Disease-free interval; NSCLC: Non-small cell lung cancer.}

\section{Competing interests}

The authors declare that they have no competing interests.

\section{Authors' contributions}

HF carried out the literature searching and manuscript drafting, WG carried out the sequence alignment and revision of the manuscript, YKY proposed the whole idea of the paper and context editing. All authors read and approved the final manuscript.

\section{Acknowledgments}

This work was supported by grants from the Natural Science Foundation of China (No. 81101507) to Fang Huang, and Natural Science Foundation of

China (No. 81172121) to Kunyu Yang.

Received: 7 May 2014 Accepted: 4 October 2014

Published online: 31 October 2014

\section{References}

1. Weichselbaum RR, Hellman S: Oligometastases revisited. Nat Rev Clin Oncol 2011, 8:378-382

2. Hellman S, Weichselbaum RR: Oligometastases. J Clin Oncol 1995, 13:8-10.

3. Niibe $Y$, Hayakawa K: Oligometastases and oligo-recurrence: the new era of cancer therapy. Jpn J Clin Oncol 2010, 40:107-111.
4. Niibe Y, Chang JY: Novel insights of oligometastases and oligo-recurrence and review of the literature. Pulm Med 2012, 2012:261096.

5. Navin N, Kendall J, Troge J, Andrews P, Rodgers L, Mclndoo J, Cook K, Stepansky A, Levy D, Esposito D, Muthuswamy L, Krasnitz A, McCombie R, Wigler M: Tumour evolution inferred by single-cell sequencing. Nature 2011, 472:90-94

6. Fidler IJ, Kripke ML: Metastasis results from preexisting variant cells within a malignant tumor. Science (New York, NY) 1977, 197:893-895.

7. Shindo-Okada N, Takeuchi K, Nagamachi Y: Establishment of cell lines with high- and low-metastatic potential from PC-14 human lung adenocarcinoma. Jpn J Cancer Res 2001, 92:174-183.

8. Li Y, Tang ZY, Ye SL, Liu YK, Chen J, Xue Q, Chen J, Gao DM, Bao WH: Establishment of cell clones with different metastatic potential from the metastatic hepatocellular carcinoma cell line MHCC97. World J Gastroenterol 2001, 7:630-636.

9. Chambers AF, Hill RP, Ling V: Tumor heterogeneity and stability of the metastatic phenotype of mouse KHT sarcoma cells. Cancer Res 1981, 41:1368-1372.

10. Yachida S, Jones S, Bozic I, Antal T, Leary R, Fu B, Kamiyama M, Hruban RH, Eshleman JR, Nowak MA, Velculescu VE, Kinzler KW, Vogelstein B, lacobuzio-Donahue CA: Distant metastasis occurs late during the genetic evolution of pancreatic cancer. Nature 2010, 467:1114-1117.

11. Wuttig D, Baier B, Fuessel S, Meinhardt M, Herr A, Hoefling C, Toma M, Grimm MO, Meye A, Rolle A, Wirth MP: Gene signatures of pulmonary metastases of renal cell carcinoma reflect the disease-free interval and the number of metastases per patient. Int J Cancer 2009, 125:474-482.

12. Tomlinson JS, Jarnagin WR, DeMatteo RP, Fong $Y$, Kornprat $P$, Gonen $M$, Kemeny N, Brennan MF, Blumgart LH, D'Angelica M: Actual 10-year survival after resection of colorectal liver metastases defines cure. J Clin Oncol 2007, 25:4575-4580.

13. Bergenfeldt M, Jensen BV, Skjoldbye B, Nielsen D: Liver resection and local ablation of breast cancer liver metastases-a systematic review. Eur J Surg Oncol 2011, 37:549-557.

14. Saxena A, Chua TC, Perera M, Chu F, Morris DL: Surgical resection of hepatic metastases from neuroendocrine neoplasms: a systematic review. Surg Oncol 2012, 21:e131-141.

15. Mariani P, Piperno-Neumann S, Servois V, Berry MG, Dorval T, Plancher C, Couturier J, Levy-Gabriel C, Lumbroso-Le Rouic L, Desjardins L, Salmon RJ: Surgical management of liver metastases from uveal melanoma: 16 years' experience at the Institut Curie. Eur J Surg Oncol 2009, 35:1192-1197.

16. Ercolani G, Grazi GL, Ravaioli M, Ramacciato G, Cescon M, Varotti G, Del Gaudio M, Vetrone G, Pinna AD: The role of liver resections for noncolorectal, nonneuroendocrine metastases: experience with 142 observed cases. Ann Surg Oncol 2005, 12:459-466.

17. Adam R, Chiche L, Aloia T, Elias D, Salmon R, Rivoire M, Jaeck D, Saric J, Le Treut YP, Belghiti J, Mantion G, Mentha G: Hepatic resection for noncolorectal nonendocrine liver metastases: analysis of 1,452 patients and development of a prognostic model. Ann Surg 2006, 244:524-535.

18. Reddy SK, Barbas AS, Marroquin CE, Morse MA, Kuo PC, Clary BM: Resection of noncolorectal nonneuroendocrine liver metastases: a comparative analysis. J Am Coll Surg 2007, 204:372-382.

19. Hoffmann K, Franz C, Hinz U, Schirmacher P, Herfarth C, Eichbaum M, Buchler MW, Schemmer P: Liver resection for multimodal treatment of breast cancer metastases: identification of prognostic factors. Ann Surg Oncol 2010, 17:1546-1554.

20. Rehders A, Peiper M, Stoecklein NH, Alexander A, Boelke E, Knoefel WT, Rogiers X: Hepatic metastasectomy for soft-tissue sarcomas: is it justified? World J Surg 2009, 33:111-117.

21. Small R, Lubezky N, Ben-Haim M: Current controversies in the surgical management of colorectal cancer metastases to the liver. Isr Med Assoc J 2007, 9:742-747.

22. Lawrence TS, Robertson JM, Anscher MS, Jirtle RL, Ensminger WD, Fajardo LF: Hepatic toxicity resulting from cancer treatment. Int J Radiat Oncol Biol Phys 1995, 31:1237-1248.

23. Mendez Romero A, Hoyer M: Radiation therapy for liver metastases. Curr Opin Support Palliat Care 2012, 6:97-102.

24. Wada H, Takai Y, Nemoto K, Yamada S: Univariate analysis of factors correlated with tumor control probability of three-dimensional conformal hypofractionated high-dose radiotherapy for small pulmonary or hepatic tumors. Int J Radiat Oncol Biol Phys 2004, 58:1114-1120. 
25. Sawrie SM, Fiveash JB, Caudell JJ: Stereotactic body radiation therapy for liver metastases and primary hepatocellular carcinoma: normal tissue tolerances and toxicity. Cancer Control 2010, 17:111-119.

26. Lanciano R, Lamond J, Yang J, Feng J, Arrigo S, Good M, Brady L: Stereotactic body radiation therapy for patients with heavily pretreated liver metastases and liver tumors. Front Oncol 2012, 2:23.

27. Katz AW, Carey-Sampson M, Muhs AG, Milano MT, Schell MC, Okunieff P: Hypofractionated stereotactic body radiation therapy (SBRT) for limited hepatic metastases. Int J Radiat Oncol Biol Phys 2007, 67:793-798.

28. Herfarth KK, Debus J, Lohr F, Bahner ML, Rhein B, Fritz P, Hoss A, Schlegel W, Wannenmacher MF: Stereotactic single-dose radiation therapy of liver tumors: results of a phase I/II trial. J Clin Oncol 2001, 19:164-170.

29. Kavanagh BD, Schefter TE, Cardenes HR, Stieber WW, Raben D, Timmerman RD, McCarter MD, Burri S, Nedzi LA, Sawyer TE, Gaspar LE: Interim analysis of a prospective phase I/II trial of SBRT for liver metastases. Acta Oncol 2006, 45:848-855.

30. Lee MT, Kim JJ, Dinniwell R, Brierley J, Lockwood G, Wong R, Cummings B, Ringash J, Tse RV, Knox JJ, Dawson LA: Phase I study of individualized stereotactic body radiotherapy of liver metastases. J Clin Oncol 2009, 27:1585-1591.

31. Mendez Romero A, Wunderink W, Hussain SM, De Pooter JA, Heijmen BJ, Nowak PC, Nuyttens JJ, Brandwijk RP, Verhoef C, ljzermans JN, Levendag PC: Stereotactic body radiation therapy for primary and metastatic liver tumors: A single institution phase i-ii study. Acta Oncol 2006, 45:831-837

32. Rule W, Timmerman R, Tong L, Abdulrahman R, Meyer J, Boike T, Schwarz RE, Weatherall P, Chinsoo Cho L: Phase I dose-escalation study of stereotactic body radiotherapy in patients with hepatic metastases. Ann Surg Oncol 2011, 18:1081-1087.

33. Rusthoven KE, Kavanagh BD, Cardenes H, Stieber WW, Burri SH, Feigenberg SJ, Chidel MA, Pugh TJ, Franklin W, Kane M, Gaspar LE, Schefter TE: Multi-institutional phase I/II trial of stereotactic body radiation therapy for liver metastases. J Clin Oncol 2009, 27:1572-1578.

34. Schefter TE, Kavanagh BD, Timmerman RD, Cardenes HR, Baron A, Gaspar LE: A phase I trial of stereotactic body radiation therapy (SBRT) for liver metastases. Int J Radiat Oncol Biol Phys 2005, 62:1371-1378.

35. Long-term results of lung metastasectomy: prognostic analyses based on 5206 cases. The International Registry of Lung Metastases. J Thorac Cardiovasc Surg 1997, 113:37-49

36. Choong PF, Pritchard DJ, Rock MG, Sim FH, Frassica FJ: Survival after pulmonary metastasectomy in soft tissue sarcoma Prognostic factors in 214 patients. Acta Orthop Scand 1995, 66:561-568.

37. Casiraghi M, De Pas T, Maisonneuve P, Brambilla D, Ciprandi B, Galetta D, Borri A, Gasparri R, Petrella F, Tessitore A, Guarize J, Donghi SM, Veronesi G, Solli P, Spaggiari L: A 10-year single-center experience on 708 lung metastasectomies: the evidence of the "international registry of lung metastases". J Thorac Oncol 2011, 6:1373-1378.

38. Pfannschmidt J, Hoffmann H, Muley T, Krysa S, Trainer C, Dienemann H: Prognostic factors for survival after pulmonary resection of metastatic renal cell carcinoma. Ann Thorac Surg 2002, 74:1653-1657.

39. Kanemitsu Y, Kato T, Hirai T, Yasui K: Preoperative probability model for predicting overall survival after resection of pulmonary metastases from colorectal cancer. Br J Surg 2004, 91:112-120.

40. Petersen RP, Hanish SI, Haney JC, Miller CC 3rd, Burfeind WR Jr, Tyler DS, Seigler HF, Wolfe W, D'Amico TA, Harpole DH Jr: Improved survival with pulmonary metastasectomy: an analysis of 1720 patients with pulmonary metastatic melanoma. J Thorac Cardiovasc Surg 2007, 133:104-110.

41. Saito Y, Omiya H, Kohno K, Kobayashi T, Itoi K, Teramachi M, Sasaki M, Suzuki H, Takao H, Nakade M: Pulmonary metastasectomy for 165 patients with colorectal carcinoma: A prognostic assessment. J Thorac Cardiovasc Surg 2002, 124:1007-1013.

42. Welter S, Jacobs J, Krbek T, Krebs B, Stamatis G: Long-term survival after repeated resection of pulmonary metastases from colorectal cancer. Ann Thorac Surg 2007, 84:203-210.

43. Meimarakis G, Angele M, Staehler M, Clevert DA, Crispin A, Ruttinger D, Lohe F, Preissler G, Hatz RA, Winter H: Evaluation of a new prognostic score (Munich score) to predict long-term survival after resection of pulmonary renal cell carcinoma metastases. Am J Surg 2011, 202:158-167.

44. Liu D, Abolhoda A, Burt ME, Martini N, Bains MS, Downey RJ, Rusch WW, Bosl GJ, Ginsberg RJ: Pulmonary metastasectomy for testicular germ cell tumors: a 28-year experience. Ann Thorac Surg 1998, 66:1709-1714.
45. Suri RM, Deschamps C, Cassivi SD, Nichols FC 3rd, Allen MS, Schleck CD, Pairolero PC: Pulmonary resection for metastatic malignant fibrous histiocytoma: an analysis of prognostic factors. Ann Thorac Surg 2005, 80:1847-1852.

46. Clavero JM, Deschamps C, Cassivi SD, Allen MS, Nichols FC 3rd, Barrette BA Larson DR, Pairolero PC: Gynecologic cancers: factors affecting survival after pulmonary metastasectomy. Ann Thorac Surg 2006, 81:2004-2007.

47. Garcia Franco CE, Torre W, Tamura A, Guillen-Grima F, San-Julian M, MartinAlgarra S, Pardo FJ: Long-term results after resection for bone sarcoma pulmonary metastases. Eur J Cardiothorac Surg 2010, 37:1205-1208.

48. Guckenberger M, Wulf J, Mueller G, Krieger T, Baier K, Gabor M, Richter A, Wilbert J, Flentje M: Dose-response relationship for image-guided stereotactic body radiotherapy of pulmonary tumors: relevance of 4D dose calculation. Int J Radiat Oncol Biol Phys 2009, 74:47-54.

49. Hamamoto Y, Kataoka M, Yamashita M, Nogami N, Sugawara Y, Kozuki T, Sawada S, Suehisa H, Shinohara S, Nakajima N, Shinkai T: Factors affecting the local control of stereotactic body radiotherapy for lung tumors including primary lung cancer and metastatic lung tumors. Jpn J Radiol 2012, 30:430-434.

50. Norihisa Y, Nagata Y, Takayama K, Matsuo Y, Sakamoto T, Sakamoto M, Mizowaki T, Yano S, Hiraoka M: Stereotactic body radiotherapy for oligometastatic lung tumors. Int J Radiat Oncol Biol Phys 2008, 72:398-403.

51. Okunieff P, Petersen AL, Philip A, Milano MT, Katz AW, Boros L, Schell MC Stereotactic Body Radiation Therapy (SBRT) for lung metastases. Acta Oncol 2006, 45:808-817.

52. Ricardi U, Filippi AR, Guarneri A, Ragona R, Mantovani C, Giglioli F, Botticella A Ciammella P, Iftode C, Buffoni L, Ruffinie E, Scagliottif GV: Stereotactic body radiation therapy for lung metastases. Lung Cancer 2012, 75:77-81.

53. Takahashi W, Yamashita H, Niibe Y, Shiraishi K, Hayakawa K, Nakagawa K: Stereotactic body radiotherapy for metastatic lung cancer as oligo-recurrence: an analysis of 42 cases. Pulmonary medicine 2012, 2012:454107.

54. Takahashi W, Nakajima M, Yamamoto N, Yamada S, Yamashita H, Nakagawa K, Tsuji H, Kamada T: Carbon ion radiotherapy for oligo-recurrent lung metastases from colorectal cancer: a feasibility study. Radiat Oncol 2014, 9:68.

55. Rusthoven KE, Kavanagh BD, Burri SH, Chen C, Cardenes H, Chidel MA, Pugh TJ, Kane M, Gaspar LE, Schefter TE: Multi-institutional phase I/II trial of stereotactic body radiation therapy for lung metastases. J Clin Oncol 2009, 27:1579-1584.

56. Hof H, Hoess A, Oetzel D, Debus J, Herfarth K: Stereotactic single-dose radiotherapy of lung metastases. Strahlenther Onkol 2007, 183:673-678.

57. Fritz P, Kraus HJ, Muhlnickel W, Hammer U, Dolken W, Engel-Riedel W, Chemaissani A, Stoelben E: Stereotactic, single-dose irradiation of stage I non-small cell lung cancer and lung metastases. Radiat Oncol 2006, 1:30.

58. Hamamoto $Y$, Kataoka M, Yamashita M, Shinkai T, Kubo Y, Sugawara Y, Inoue T, Sakai S, Aono S, Takahashi T, Semb T, Uwatsu K: Local control of metastatic lung tumors treated with SBRT of $48 \mathrm{~Gy}$ in four fractions: in comparison with primary lung cancer. Jpn J Clin Oncol 2010, 40:125-129.

59. Takeda A, Kunieda E, Ohashi T, Aoki Y, Koike N, Takeda T: Stereotactic body radiotherapy (SBRT) for oligometastatic lung tumors from colorectal cancer and other primary cancers in comparison with primary lung cancer. Radiother Oncol 2011, 101:255-259.

60. Baschnagel AM, Mangona VS, Robertson JM, Welsh RJ, Kestin LL, Grills IS: Lung metastases treated with image-guided stereotactic body radiation therapy. Clin Oncol 2013, 25:236-241.

61. Muth A, Persson F, Jansson S, Johanson V, Ahlman H, Wangberg B: Prognostic factors for survival after surgery for adrenal metastasis. Eur J Surg Oncol 2010, 36:699-704.

62. Zheng QY, Zhang GH, Zhang Y, Guo YL: Adrenalectomy may increase survival of patients with adrenal metastases. Oncology letters 2012, 3:917-920.

63. Suzuki H: Laparoscopic adrenalectomy for adrenal carcinoma and metastases. Curr Opin Urol 2006, 16:47-53.

64. Chawla S, Chen Y, Katz AW, Muhs AG, Philip A, Okunieff P, Milano MT: Stereotactic body radiotherapy for treatment of adrenal metastases. Int J Radiat Oncol Biol Phys 2009, 75:71-75.

65. Torok J, Wegner RE, Burton SA, Heron DE, Torok J, Wegner RE, Burton SA, Heron DE: Stereotactic body radiation therapy for adrenal metastases: a retrospective review of a noninvasive therapeutic strategy. Future Oncol 2011, 7:145-151.

66. Chamberlain MC: Spinal metastases from lung cancer-who benefits from decompression surgery? Nat Clin Pract Neurol 2007, 3:188-189. 
67. Choi D, Morris S, Crockard A, Albert T, Bunger C, Fehlings M, Harrop J, Kawahara N, Martin JA, Massicotte EM, Mazel C, Oner FC, Peul W, Tomita K, Wang M: Assessment of quality of life after surgery for spinal metastases: position statement of the Global Spine Tumour Study Group. World Neurosurg 2013, 80:e175-179.

68. Lo SS, Sahgal A, Wang JZ, Mayr NA, Sloan A, Mendel E, Chang EL: Stereotactic body radiation therapy for spinal metastases. Discov Med 2010, 9:289-296.

69. Lopes JC, Navarro A, Sole JM, Martinez M, Guedea F: Stereotactic body radiation therapy for spinal metastases. Clin Trans/ Oncol 2010, 12:639-642.

70. Cunha MV, Al-Omair A, Atenafu EG, Masucci GL, Letourneau D, Korol R, Yu E, Howard P, Lochray F, da Costa LB, Fehlings MG, Sahgal A: Vertebral compression fracture (VCF) after spine stereotactic body radiation therapy (SBRT): analysis of predictive factors. Int J Radiat Oncol Biol Phys 2012, 84:e343-349.

71. Boehling NS, Grosshans DR, Allen PK, McAleer MF, Burton AW, Azeem S, Rhines LD, Chang EL: Vertebral compression fracture risk after stereotactic body radiotherapy for spinal metastases. J Neurosurg Spine 2012, 16:379-386.

72. Widder J, Klinkenberg TJ, Ubbels JF, Wiegman EM, Groen HJ, Langendijk JA: Pulmonary oligometastases: metastasectomy or stereotactic ablative radiotherapy? Radiother Oncol 2013, 107:409-413.

73. de Vin T, Engels B, Gevaert T, Storme G, De Ridder M: Stereotactic radiotherapy for oligometastatic cancer: a prognostic model for survival. Ann Oncol 2014, 25:467-471.

74. Milano MT, Katz AW, Zhang H, Okunieff P: Oligometastases treated with stereotactic body radiotherapy: long-term follow-up of prospective study. Int J Radiat Oncol Biol Phys 2012, 83:878-886.

75. Goslin R, Steele G Jr, Zamcheck N, Mayer R, Maclntyre J: Factors influencing survival in patients with hepatic metastases from adenocarcinoma of the colon or rectum. Dis Colon Rectum 1982, 25:749-754.

76. Choti MA, Sitzmann JV, Tiburi MF, Sumetchotimetha W, Rangsin R, Schulick RD, Lillemoe KD, Yeo CJ, Cameron JL: Trends in long-term survival following liver resection for hepatic colorectal metastases. Ann Surg 2002, 235:759-766.

77. Giuliante F, Ardito F, Vellone M, Ranucci G, Federico B, Giovannini I, Nuzzo G: Role of the surgeon as a variable in long-term survival after liver resection for colorectal metastases. J Surg Oncol 2009, 100:538-545.

78. Simmonds PC, Primrose JN, Colquitt JL, Garden OJ, Poston GJ, Rees M: Surgical resection of hepatic metastases from colorectal cancer: a systematic review of published studies. Br J Cancer 2006, 94:982-999.

79. Suemitsu R, Takeo S, Kusumoto E, Hamatake M, Ikejiri K, Saitsu H: Results of a pulmonary metastasectomy in patients with colorectal cancer. Surg Today 2011, 41:54-59.

80. Inoue M, Ohta M, luchi K, Matsumura A, Ideguchi K, Yasumitsu T, Nakagawa K, Fukuhara K, Maeda H, Takeda S, Minami M, Ohno Y, Matsuda H: Benefits of surgery for patients with pulmonary metastases from colorectal carcinoma. Ann Thorac Surg 2004, 78:238-244.

81. Salah S, Watanabe K, Welter S, Park JS, Park JW, Zabaleta J, Ardissone F, Kim J, Riquet M, Nojiri K, Gisabella M, Kim SY, Tanaka K, Ali BA: Colorectal cancer pulmonary oligometastases: pooled analysis and construction of a clinical lung metastasectomy prognostic model. Ann Oncol 2012, 23:2649-2655.

82. Meimarakis G, Ruttinger D, Stemmler J, Crispin A, Weidenhagen R, Angele M, Fertmann J, Hatz RA, Winter H: Prolonged overall survival after pulmonary metastasectomy in patients with breast cancer. Ann Thorac Surg 2013, 95:1170-1180.

83. Ashworth A, Rodrigues G, Boldt G, Palma D: Is there an oligometastatic state in non-small cell lung cancer? A systematic review of the literature. Lung Cancer 2013, 82:197-203.

84. Patchell RA, Tibbs PA, Walsh JW, Dempsey RJ, Maruyama Y, Kryscio RJ, Markesbery WR, Macdonald JS, Young B: A randomized trial of surgery in the treatment of single metastases to the brain. N Engl J Med 1990, 322:494-500.

85. Andrews DW, Scott CB, Sperduto PW, Flanders AE, Gaspar LE, Schell MC, Werner-Wasik M, Demas W, Ryu J, Bahary JP, Souhami L, Rotman M, Mehta MP, Curran WJ: Whole brain radiation therapy with or without stereotactic radiosurgery boost for patients with one to three brain metastases: phase III results of the RTOG 9508 randomised trial. Lancet 2004, 363:1665-1672.
86. Spelt L, Andersson B, Nilsson J, Andersson R: Prognostic models for outcome following liver resection for colorectal cancer metastases: A systematic review. Eur J Surg Oncol 2012, 38:16-24.

87. Kanzaki R, Higashiyama M, Fujiwara A, Tokunaga T, Maeda J, Okami J, Nishimura K, Kodama K: Long-term results of surgical resection for pulmonary metastasis from renal cell carcinoma: a 25-year single-institution experience. Eur J Cardiothorac Surg 2011, 39:167-172.

88. Rees M, Tekkis PP, Welsh FK, O'Rourke T, John TG: Evaluation of long-term survival after hepatic resection for metastatic colorectal cancer: a multifactorial model of 929 patients. Ann Surg 2008, 247:125-135.

89. Konopke R, Kersting S, Distler M, Dietrich J, Gastmeier J, Heller A, Kulisch E, Saeger HD: Prognostic factors and evaluation of a clinical score for predicting survival after resection of colorectal liver metastases. Liver Int 2009, 29:89-102.

90. Malik HZ, Prasad KR, Halazun KJ, Aldoori A, Al-Mukhtar A, Gomez D, Lodge JP, Toogood GJ: Preoperative prognostic score for predicting survival after hepatic resection for colorectal liver metastases. Ann Surg 2007, 246:806-814.

91. Minagawa M, Yamamoto J, Kosuge T, Matsuyama Y, Miyagawa S, Makuuchi M: Simplified staging system for predicting the prognosis of patients with resectable liver metastasis: development and validation. Arch Surg 2007, 142:269-276. discussion 277

92. Lussier YA, Khodarev NN, Regan K, Corbin K, Li H, Ganai S, Khan SA, Gnerlich JL, Darga TE, Fan H, Karpenko O, Paty PB, Posner MC, Chmura SJ, Hellman S, Ferguson MK, Weichselbaum RR: Oligo- and polymetastatic progression in lung metastasis(es) patients is associated with specific microRNAs. PLoS One 2012, 7:e50141

doi:10.1186/s13014-014-0230-6

Cite this article as: Huang et al:: Oligometastasis and oligo-recurrence: more than a mirage. Radiation Oncology 2014 9:230.

\section{Submit your next manuscript to BioMed Central and take full advantage of:}

- Convenient online submission

- Thorough peer review

- No space constraints or color figure charges

- Immediate publication on acceptance

- Inclusion in PubMed, CAS, Scopus and Google Scholar

- Research which is freely available for redistribution

Submit your manuscript at www.biomedcentral.com/submit
C) Biomed Central 